\title{
Penerapan Teknik Silvikultur Intensif Pada Pengelolaan Hutan Rakyat di Kabupaten Gunungkidul
}

\author{
Wiyono $^{1^{*}}$, Puji Lestari ${ }^{2}$, Rochmat Hidayat ${ }^{3}$, Silvi Nur Oktalina ${ }^{4}$, Singgih Utomo5, Eko \\ Prasetyo $^{6}$, Agus Ngadianto ${ }^{7}$, Prasetyo Nugroho ${ }^{8}$ \\ 1,2,3,3,5,5,6,7,8 Program Studi Pengelolaan Hutan, Departemen Teknologi Hayati dan Veteriner, \\ Sekolah Vokasi, Universitas Gadjah Mada \\ *Email: wiyono.putro@ugm.ac.id
}

\begin{abstract}
Abstrak
Masyarakat Gunungkidul telah memiliki pengalaman panjang dalam melakukan rehabilitasi lahan kritis menjadi hutan rakyat yang produktif. Namun demikian, pada umumnya kayu jati dari hutan rakyat Gunungkidul kualitasnya masih jauh lebih rendah dibandingkan dengan kayu jati dari Perum Perhutani. Salah satu penyebabnya karena para petani hutan rakyat di Gunungkidul masih belum menerapkan teknik silvikultur intensif. Kegiatan pengabdian kepada masyarakat ini bertujuan untuk: (1) Meningkatkan pengetahuan petani hutan rakyat tentang teknik silvikultur intensif; (2) Meningkatkan kesadaran petani hutan rakyat tentang pentingnya penerapan teknik silvikultur intensif; (3) Meningkatkan ketrampilan petani hutan rakyat tentang teknik silvikultur intensif; (4) Mendorong kemandirian petani hutan rakyat dalam penyediaan bibit jati unggul dan pupuk organik. Kegiatan pengabdian kepada masyarakat ini dilaksanakan di Kelompok Tani Ngudi Makmur, Desa Watusigar, Kecamatan Ngawen, Kabupaten Gunungkidul pada tahun 2015 - 2016. Program pengabdian kepada masyarakat ini dilaksanakan dengan menggunakan metode sosialisasi, studi banding, pelatihan, praktek lapangan dan pendampingan petani. Kegiatan ini telah berhasil membuat demplot tegakan jati unggul, kebun pangkas jati unggul, persemaian jati unggul, dan pupuk organik dengan jamur Trichoderma sp. Kegiatan ini juga telah berhasil meningkatkan pengetahuan, kesadaran, ketrampilan dan kemandirian petani hutan rakyat dalam menerapkan teknik silvikultur intensif.
\end{abstract}

Kata Kunci: hutan rakyat, silvikultur intensif, jati unggul, pupuk organik.

\begin{abstract}
The people of Gunungkidul have long experience in rehabilitation program. They manage marginal land be productive community forest. While, the quality of timber from community forest is lower than produced by Perhutani. It is caused the community forest has not been applied intensive silviculture technique. This community engagement program aims to: (1) up grade the farmer knowledge about intensive silviculture technique; (2) rise the farmer awareness for importance of applying intensive silviculture technique; (3) build up the farmer skill to apply intensive silviculture technique; (4) motivate the farmer to produce superior teak seedling and organic fertilizer independently. The target group of this program is the farmer group of Ngudi Makmur at Watusigar Village, Ngawen District, Gunungkidul Regency. This program was held on 2015 to 2016. The methods applied in this program are socialization, field study, training, practice, and technical assistance. The results of this program are demonstration plot of superior teak stand, hedge orchard and nursery of superior teak, and organic fertilizer using Trichoderma sp. This program also succesfull for increase of knowledge, awareness, skills and independence offarmer in applying of intensive silviculture technique.
\end{abstract}


Keywords: community forest, intensive silviculture, superior teak, organic fertilize

\section{PENDAHULUAN}

Menurut Undang-Undang nomor 41 tahun 1999 tentang Kehutanan, hutan rakyat disebut sebagai hutan hak, yaitu hutan yang tumbuh di atas tanah yang dibebani hak atas tanah (Anonim, 1999). Pengelolaan hutan rakyat dapat dilakukan secara perorangan maupun berkelompok (Awang, et al., 2001). Hutan rakyat merupakan satuan ekosistem kehidupan mulai dari tanaman keras, non kayu, satwa, buah-buahan, satuan usaha tani semusim, peternakan dan jasa rekreasi alam, baik ditanam secara campuran maupun hanya sejenis saja (Simon, 2010; Awang, et al., 2002). Hutan rakyat dapat berupa pekarangan, tegalan, dan wana (Awang, et al., 2001; Hinrichs, et al., 2008; Simon, 2010).

Hutan rakyat yang bagus mempunyai beragam manfaat dan menempati posisi strategis dalam pembangunan nasional, karena: (1) Meningkatkan produksi kayu dan hasil hutan ikutan lainnya; (2) Meningkatkan kesempatan kerja; (3) Memperbaiki sistem tata air; (4) Meningkatkan proses penyerapan karbon monooksida dan polutan lain dari udara; (5) Meningkatkan suplai oksigen ke udara; (6) Menjadi habitat yang baik bagi satwa dan menjaga keanekaragaman hayati (Awang, et al, 2001; Simon, 2010). Salah satu contoh pembangunan hutan rakyat yang berhasil adalah di Kabupaten Gunungkidul.

Masyarakat Gunungkidul telah memiliki pengalaman panjang dalam pengelolaan hutan rakyat. Jika pada dekade 1960-an wilayah Kabupaten Gunungkidul dikenal sebagai daerah yang tandus dan kritis, saat ini telah berubah menjadi hijau dan subur (Simon, 2010). Perubahan kondisi tutupan lahan di Kabupaten Gunungkidul ini tidak terlepas dari semakin berkembangnya hutan rakyat. Sejak dekade 1970-an masyarakat Gunungkidul giat melakukan rehabilitasi lahan kritis menjadi lahan produktif, baik disubsidi oleh pemerintah melalui program penghijauan maupun secara swadaya. Jenis tanaman berkayu yang paling banyak ditanam oleh masyarakat Gunungkidul di hutan rakyat adalah jati (Tectona grandis).

Seiring dengan meningkatnya permintaan pasar terhadap kayu dari hutan rakyat, semangat masyarakat Gunungkidul mengembangkan hutan rakyat semakin tinggi. Menurut Bappeda DIY (2015) luas hutan rakyat di Kabupaten Gunungkidul pada tahun 2006 adalah 28.630 ha dan meningkat menjadi $31.671,83$ ha pada tahun 2010. Produksi kayu dari hutan rakyat di Kabupaten Gunungkidul sekitar 100.00o $\mathrm{m}^{3}$ per tahun dan $80.000 \mathrm{~m}^{3}$ diantaranya adalah kayu jati (Berita Bumi, 2015). Peningkatan luas dan produksi hutan rakyat di Gunungkidul tersebut, ternyata tidak diimbangi dengan kualitas kayu yang dihasilkan. Kayu jati dari hutan rakyat Gunungkidul kualitasnya masih lebih rendah dibandingkan dengan kayu jati dari Perum Perhutani. Kayu jati dari hutan rakyat Gunungkidul banyak memiliki mata kayu, bengkok, growong, dan kayu gubalnya tebal. Akibatnya harga jualnya jauh lebih rendah dibandingkan dengan harga kayu jati dari Perum Perhutani.

Rendahnya kualitas kayu jati dari hutan rakyat Gunungkidul tersebut karena selama ini pengelolaanya masih bersifat konvensional. Sentuhan teknik silvikultur yang diberikan pada pengelolaan hutan rakyat di Kabupaten Gunungkidul masih sangat terbatas. Kebutuhan akan materi tanaman (planting stock) jati di hutan rakyat pada umumnya bertumpu pada tersedianya benih atau semai melalui cara tradisional, antara lain melalui biji, cabutan dan trubusan. Akibatnya kuantitas dan kualitas benih sangat terbatas, prosentase kecambah rendah, variasi semai sangat tinggi dan perolehan genetiknya tidak optimal. Selain itu, teknik penanaman dan pemeliharaan juga tidak diperhatikan secara khusus. Pada umumnya penanaman jati di hutan rakyat dilakukan tanpa ada tambahan input pupuk dan pembuatan lubang tanam yang tidak memadai. Kemudian setelah ditanam tanaman jati dibiarkan tumbuh 
secara alami tanpa tindakan pemeliharaan yang berarti.

Berdasarkan permasalahan tersebut, maka diperlukan suatu upaya untuk membantu masyarakat Gunungkidul meningkatkan kualitas kayu jati dari hutan rakyat dan salah satunya adalah dengan menerapkan teknik silvikultur intensif (SILIN). Menurut Soekotjo (2009) silvikultur intensif adalah teknik silvikultur yang memadukan elemen utama silvikultur, yaitu: (1) penggunaan bibit unggul; (2) manipulasi lingkungan; (3) pengendalian hama terpadu. Sementara itu, menurut Na'iem (2005) teknik silvikultur intensif adalah penggunaan benih yang bergenetik unggul dan ditanam pada kondisi lingkungan yang optimal. Tujuan penerapan teknik silvikultur intensif adalah untuk memperoleh hutan tanaman, termasuk hutan rakyat yang produktif, kompetitif, efisien dan lestari. Serangkaian kegiatan pengelolaan hutan rakyat yang perlu diperhatikan dalam penerapan silvikultur intensif antara lain yaitu penggunaan bibit unggul, penentuan jarak tanam yang tepat, penggunaan jenis dan dosis pupuk yang cocok, penjarangan yang tepat, pruning yang baik, pengendalian gulma secara efektif, perlindungan dari gangguan hama dan penyakit, kebakaran, penggembalaan, dan satwa liar (Na'iem, 2005).

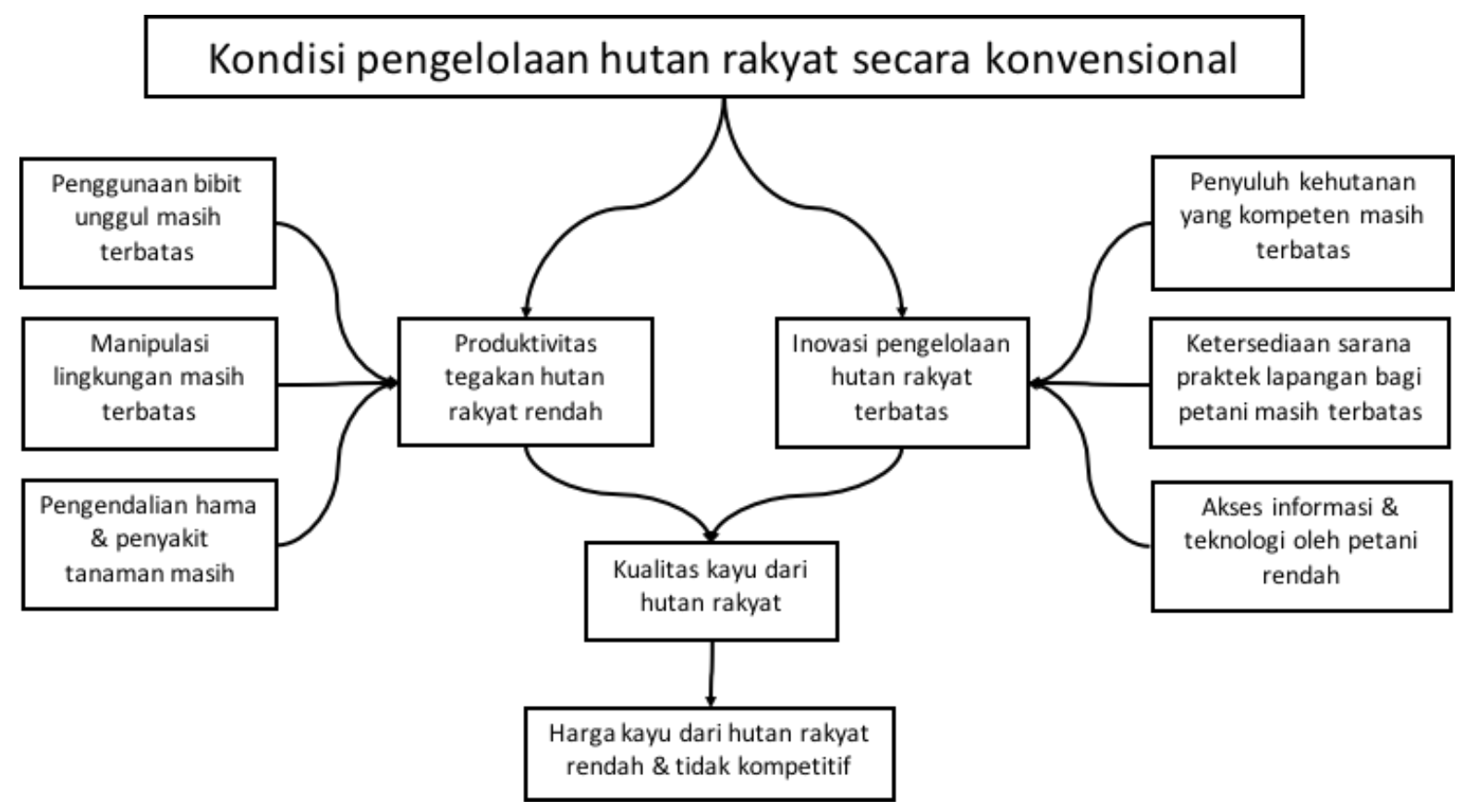

Gambar 1. Bagan alir kondisi pengelolaan

hutan rakyat secara konvensional.

Menurut Pramono, et al. (2010), penerapan teknik silvikultur intensif pada pengelolaan hutan rakyat akan memberikan beberapa manfaat, yaitu: (1) Penggunaan bibit unggul akan menghasilkan pohon yang tumbuh cepat dan berbatang lurus; (2) Pemangkasan cabang (prunning) pada saat jati berumur muda akan menghasilkan batang tanpa cacat mata kayu dan batang bebas cabang tinggi; (3) Penjarangan (thinning) akan mengurangi persaingan antar pohon dalam memperoleh makanan (hara) dari tanah dan cahaya matahari sehingga mempercepat pertumbuhan diameter 
pohon; (4) Pemupukan pada tanaman jati akan mempercepat petumbuhan sehingga menghasilkan kayu yang berukuran besar; (5) Pengendalian hama dan penyakit akan menjamin pohon tumbuh sehat dan normal sehingga menghasilkan kayu berukuran besar dan bebas dari cacat. Dengan demikian, penerapan teknik silvikultur intensif pada pengelolaan hutan rakyat akan dapat meningkatkan hasil kayu, baik kualitas maupun kuantitasnya dan dapat mempersingkat umur panen (daur) tegakan (Na'iem, 2005).

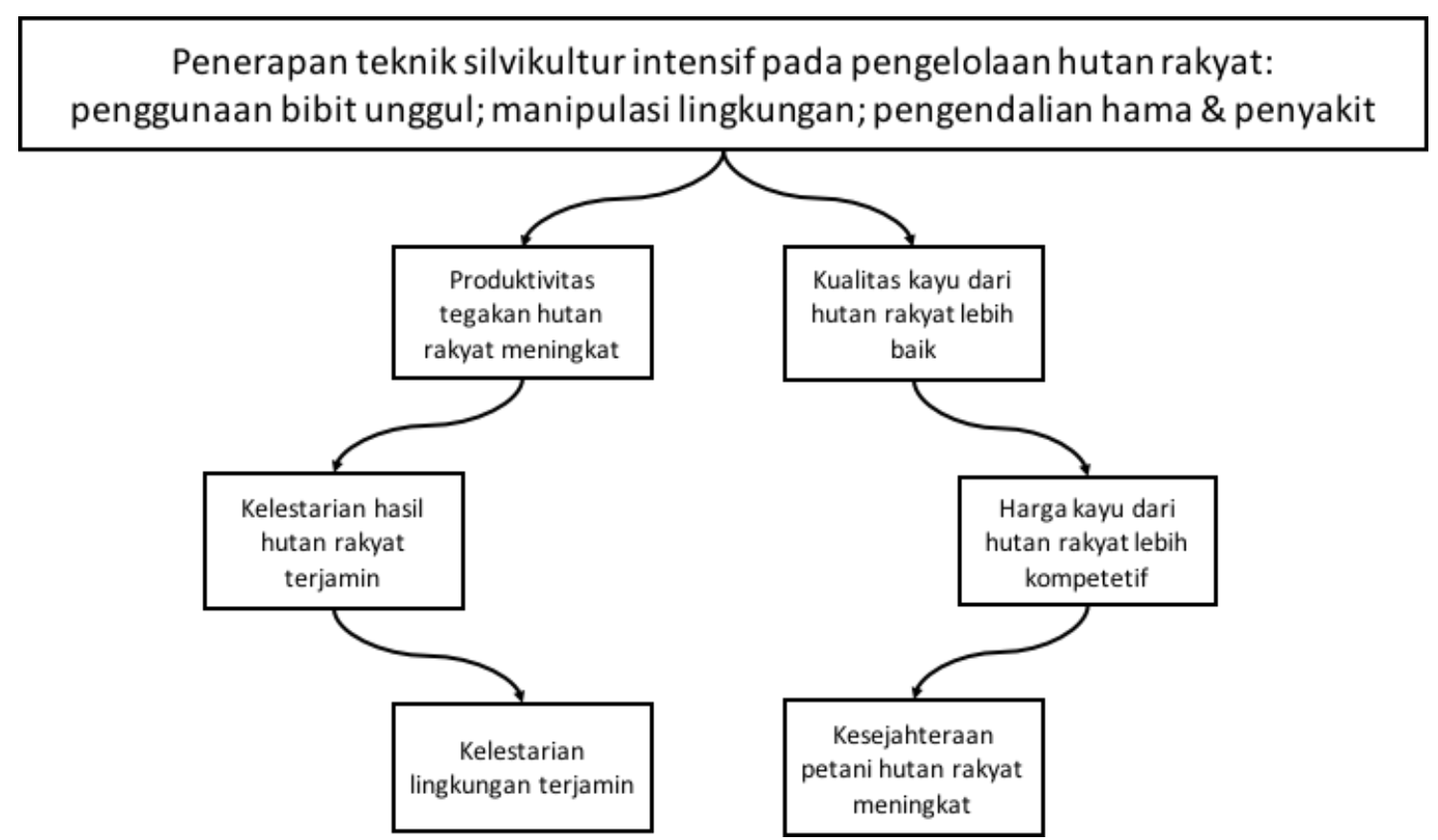

Gambar 2. Bagan alir penerapan teknik silvikultur intensif pada pengelolaan hutan rakyat

Sampai saat ini petani hutan rakyat di Kabupaten Gunungkidul masih kesulitan memperoleh informasi tentang bagaimana cara penerapan teknik silvikultur intensif di hutan rakyat. Pada umumnya informasi tersebut masih ditulis dalam bahasa ilmiah, sehingga sulit dipahami, kurang menarik dan tidak praktis bagi petani hutan rakyat. Kegiatan pengabdian kepada masyarakat ini merupakan salah satu upaya penyebaran informasi dan hilirisasi hasil riset akademik tentang teknik silvikultur intensif untuk kepentingan praktis bagi para petani hutan rakyat di Kabupaten Gunungkidul. Secara lebih spesifik, kegiatan pengabdian kepada masyarakat ini bertujuan untuk: (1) Meningkatkan pengetahuan petani hutan rakyat tentang teknik silvikultur intensif; (2) Meningkatkan kesadaran petani hutan rakyat tentang pentingnya penerapan teknik silvikultur intensif; (3) Meningkatkan ketrampilan petani hutan rakyat tentang teknik silvikultur intensif; (4) Mendorong kemandirian petani hutan rakyat dalam penyediaan bibit jati unggul dan pupuk organik.

\section{METODE}

Program pengabdian kepada masyarakat ini dilaksanakan selama dua tahun, yaitu pada tahun 2015 - 2016. Kelompok sasaran utama program adalah pengurus dan anggota Kelompok Tani Ngudi Makmur, Desa Watusigar, Kecamatan Ngawen, Kabupaten Gunungkidul. Namun demikian, pada pelaksanaannya program ini juga diikuti oleh para penyuluh kehutanan dan pegawai Dinas Kehutanan dan Perkebunan Kabupaten Gunungkidul.

Pelaksanaan program pengabdian kepada masyarakat ini menggunakan metode sosialisasi, studi banding, pelatihan, praktek lapangan, dan pendampingan 
petani. Metode tersebut kemudian dijabarkan dalam beberapa kegiatan yang dilaksanakan selama dua tahun. Kegiatan tahun pertama (2015) meliputi: (1) Sosialisasi program; (2) Pelatihan teknik silvikultur intensif; (3) Studi banding pengelolaan persemaian dan tegakan hutan tanaman jati unggul; (4) Pemberian bantuan indukan bibit jati unggul dan sarana

penunjang persemaian; (5) Praktek pembuatan kebun pangkas dan demplot tegakan jati unggul; (6) Pendampingan petani hutan rakyat. Sementara itu, kegiatan tahun kedua (2016) meliputi: (1) Sosialisasi program; (2) Pelatihan teknik pembuatan persemaian jati unggul dan pupuk organik dengan menggunakan jamur Trichoderma sp.; (3) Praktek pembuatan persemaian jati unggul dan pupuk organik dengan menggunakan jamur Trichoderma sp.; (4) Pendampingan petani hutan rakyat. Pelaksanaan masing-masing kegiatan secara rinci disajikan pada tabel berikut ini:

Tabel 1. Pelaksanaan Kegiatan Pengabdian Kepada Masyarakat

\begin{tabular}{|c|c|c|c|c|}
\hline No. & Kegiatan & Lokasi & Tanggal & Peserta \\
\hline \multicolumn{5}{|c|}{ Tahun pertama (2015) } \\
\hline 1. & $\begin{array}{l}\text { Sosialisasi program } \\
\text { pengabdian kepada } \\
\text { masyarakat }\end{array}$ & $\begin{array}{l}\text { Desa } \\
\text { Watusigar }\end{array}$ & $\begin{array}{l}05-08- \\
2015\end{array}$ & $\begin{array}{l}\text { Pengurus Kelompok Tani } \\
\text { Ngudi Makmur; Penyuluh } \\
\text { dan Pegawai Dinas } \\
\text { Kehutanan dan Perkebunan } \\
\text { Kabupaten Gunungkidul. }\end{array}$ \\
\hline 2. & $\begin{array}{l}\text { Pelatihan teknik silvikultur } \\
\text { intensif pada pengelolaan } \\
\text { hutan rakyat }\end{array}$ & $\begin{array}{l}\text { Desa } \\
\text { Watusigar }\end{array}$ & $\begin{array}{l}21-08- \\
2015\end{array}$ & $\begin{array}{l}\text { Pengurus dan anggota } \\
\text { Kelompok Tani Ngudi } \\
\text { Makmur; Penyuluh dan } \\
\text { Pegawai Dinas Kehutanan } \\
\text { dan Perkebunan Kabupaten } \\
\text { Gunungkidul. }\end{array}$ \\
\hline 3. & $\begin{array}{l}\text { Studi banding pengelolaan } \\
\text { persemaian dan hutan } \\
\text { tanaman jati unggul }\end{array}$ & $\begin{array}{l}\text { Hutan } \\
\text { pendidikan } \\
\text { Wanagama }\end{array}$ & $\begin{array}{l}05^{-09-} \\
2015\end{array}$ & $\begin{array}{l}\text { Pengurus dan anggota } \\
\text { Kelompok Tani Ngudi } \\
\text { Makmur; Penyuluh dan } \\
\text { Pegawai Dinas Kehutanan } \\
\text { dan Perkebunan Kabupaten } \\
\text { Gunungkidul. }\end{array}$ \\
\hline 4. & $\begin{array}{l}\text { Pemberian bantuan } \\
\text { indukan bibit jati unggul } \\
\text { dan sarana penunjang } \\
\text { persemaian }\end{array}$ & $\begin{array}{l}\text { Desa } \\
\text { Watusigar }\end{array}$ & $\begin{array}{l}10-10- \\
2015\end{array}$ & $\begin{array}{l}\text { Pengurus Kelompok Tani } \\
\text { Ngudi Makmur; Penyuluh } \\
\text { dan Pegawai Dinas } \\
\text { Kehutanan dan Perkebunan } \\
\text { Kabupaten Gunungkidul. }\end{array}$ \\
\hline 5. & $\begin{array}{l}\text { Praktek pembuatan kebun } \\
\text { pangkas dan demplot } \\
\text { tegakan jati unggul }\end{array}$ & $\begin{array}{l}\text { Desa } \\
\text { Watusigar }\end{array}$ & $\begin{array}{l}12-10- \\
2015\end{array}$ & $\begin{array}{l}\text { Pengurus dan anggota } \\
\text { Kelompok Tani Ngudi } \\
\text { Makmur }\end{array}$ \\
\hline 6. & $\begin{array}{l}\text { Pendampingan petani } \\
\text { hutan rakyat }\end{array}$ & $\begin{array}{l}\text { Desa } \\
\text { Watusigar }\end{array}$ & $\begin{array}{l}15^{-11-} \\
2015\end{array}$ & $\begin{array}{l}\text { Pengurus dan anggota } \\
\text { Kelompok Tani Ngudi } \\
\text { Makmur }\end{array}$ \\
\hline
\end{tabular}


Tahun kedua (2016)

\begin{tabular}{|c|c|c|c|c|}
\hline & No. & Kegiatan & Lokasi & Tanggal \\
\hline 1. & $\begin{array}{l}\text { Sosialisasi program } \\
\text { pengabdian kepada } \\
\text { masyarakat }\end{array}$ & $\begin{array}{l}\text { Desa } \\
\text { Watusigar }\end{array}$ & $\begin{array}{l}21-06- \\
2016\end{array}$ & $\begin{array}{l}\text { Pengurus Kelompok Tani Ngudi } \\
\text { Makmur; Penyuluh dan Pegawai } \\
\text { Dinas Kehutanan dan } \\
\text { Perkebunan Kabupaten } \\
\text { Gunungkidul. }\end{array}$ \\
\hline 2. & $\begin{array}{l}\text { Pelatihan teknik pembuatan } \\
\text { persemaian jati unggul dan } \\
\text { pupuk organik dengan } \\
\text { menggunakan jamur } \\
\text { Trichoderma sp. }\end{array}$ & $\begin{array}{l}\text { Desa } \\
\text { Watusigar }\end{array}$ & $\begin{array}{l}12-08- \\
2016\end{array}$ & $\begin{array}{l}\text { Pengurus dan anggota Kelompok } \\
\text { Tani Ngudi Makmur }\end{array}$ \\
\hline 3. & $\begin{array}{l}\text { Praktek pembuatan } \\
\text { persemaian jati unggul dan } \\
\text { pupuk organik dengan } \\
\text { menggunakan jamur } \\
\text { Trichoderma sp. }\end{array}$ & $\begin{array}{l}\text { Desa } \\
\text { Watusigar }\end{array}$ & $\begin{array}{l}\text { 09-09- } \\
2016\end{array}$ & $\begin{array}{l}\text { Pengurus dan anggota Kelompok } \\
\text { Tani Ngudi Makmur }\end{array}$ \\
\hline 4 & $\begin{array}{l}\text { Pendampingan petani hutan } \\
\text { rakyat }\end{array}$ & $\begin{array}{l}\text { Desa } \\
\text { Watusigar }\end{array}$ & $\begin{array}{l}\text { o8-10- } \\
2016\end{array}$ & $\begin{array}{l}\text { Pengurus dan anggota Kelompok } \\
\text { Tani Ngudi Makmur }\end{array}$ \\
\hline
\end{tabular}

\section{HASIL DAN PEMBAHASAN}

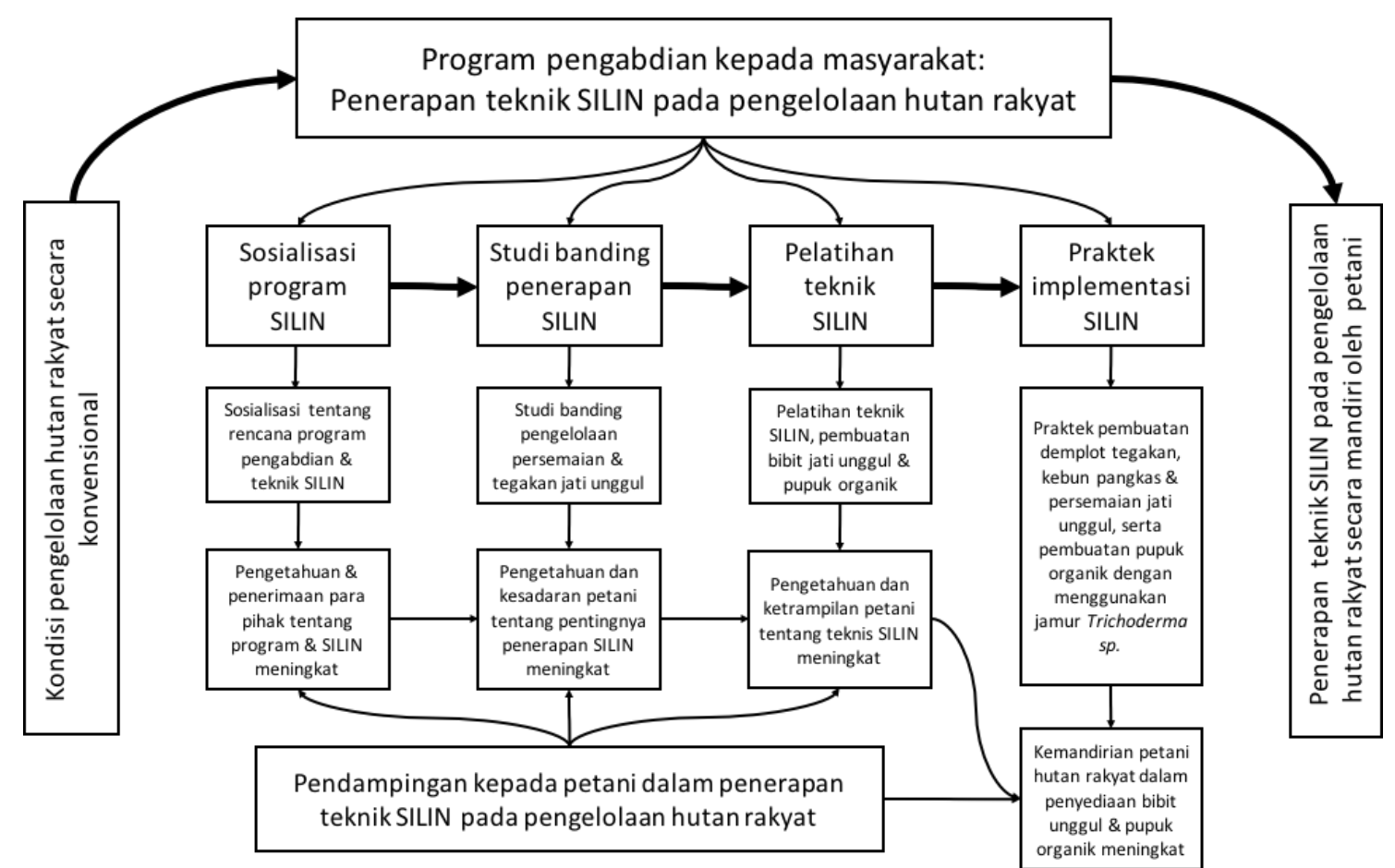

Gambar 3: Bagan alir pelaksanaan program pengabdian kepada masyarakat.

\section{Sosialisasi Program SILIN}

Sosialiasi program SILIN dimaksudkan untuk menjelaskan latar belakang dan tujuan program pengabdian kepada para pihak. Kegiatan sosialisasi ini dilakukan kepada Dinas Kehutanan dan Perkebunan Kabupaten Gunungkidul, penyuluh kehutanan Kecamatan Ngawen, dan pengurus Kelompok Tani Ngudi Makmur Desa Watusigar. Hasil sosialisasi 
menunjukkan bahwa para pihak terkait mendukung rencana program pengabdian karena dianggap dapat meningkatkan pemahaman dan ketrampilan para petani hutan rakyat tentang teknik silvikultur intensif, sehingga pada akhirnya dapat meningkatkan produktivitas tegakan dan kualitas kayu dari hutan rakyat. Dukungan dari penyuluh kehutanan dan Dinas Kehutanan dan Perkebunan Kabupaten Gunungkidul terhadap rencana program berdampak signifikan terhadap penerimaan pengurus Kelompok Tani Ngudi Makmur Desa Watusigar. Pada saat sosialisasi sekaligus dibahas bersama tentang jadwal pelaksanaan kegiatan, sarana dan bahan yang dibutuhkan, serta partisipasi parapihak yang diperlukan.

\section{Studi Banding Penerapan SILIN}

Studi banding penerapan SILIN dimaksudkan untuk menunjukkan secara langsung kepada para petani hutan rakyat tentang penerapan teknik silvikultur intensif di lapangan. Studi banding dilakukan di Hutan Pendidikan Wanagama yang dikelola oleh Fakultas Kehutanan

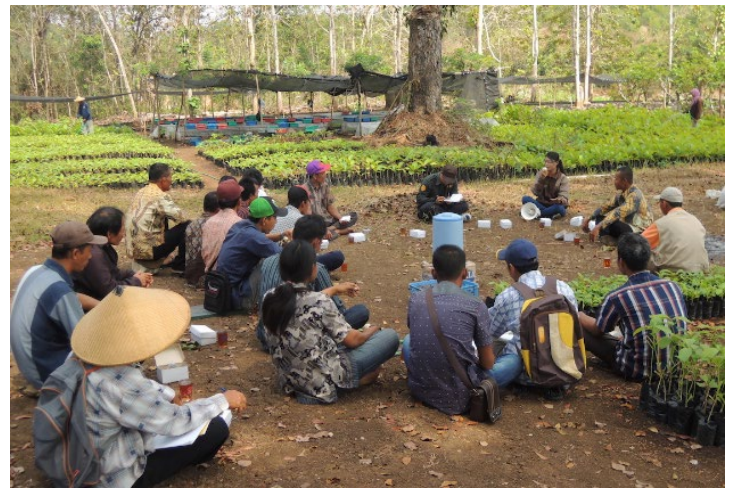

Universitas Gadjah Mada. Kegiatan studi banding ini difokuskan pada dua obyek, yaitu pengelolaan persemaian jati unggul dan pengelolaan hutan tanaman jati unggul. Output yang diharapkan dari kegiatan ini adalah meningkatnya pemahaman, kesadaran dan minat petani terhadap pentingnya penerapan teknik silvikultur intensif pada pengelolaan hutan rakyat.

Pada obyek pertama, para petani hutan rakyat diajak berkunjung ke persemaian jati unggul. Para petani ditunjukkan dan dijelaskan tentang selukbeluk pengelolaan kebun pangkas dan persemaian jati unggul. Petani juga dijelaskan tentang teknik pembuatan bibit jati unggul dengan metode stek pucuk dan okulasi. Para petani hutan rakyat terlibat aktif dalam diskusi dan simulasi pembuatan stek pucuk dan okulasi jati unggul. Menurut para petani hutan rakyat, studi banding ini sangat bermanfaat untuk menambah pengetahuan, karena sebagian besar dari para petani baru mengetahui jika tanaman jati dapat dikembangbiakkan dengan metode stek pucuk dan okulasi.

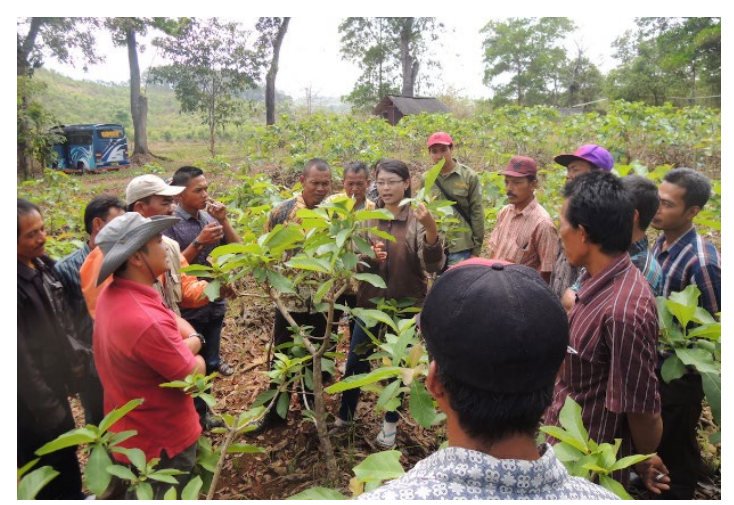

Gambar 4: Studi banding pengelolaan persemaian jati unggul di Wanagama

Pada obyek kedua, para petani hutan rakyat diajak berkunjung ke tegakan jati mega. Tegakan jati mega adalah tegakan jati unggul yang ditanam pada zaman Presiden Megawati. Para petani ditunjukkan dan dijelaskan tentang teknik pengelolaan hutan tanaman jati unggul. Petani juga dijelaskan tentang penerapan teknik silvikultur intensif, mulai dari penggunaan bibit unggul, pengolahan lahan, pengaturan jarak tanam, pemupukan, prunning, penjarangan, dan pengelolaan tanaman di bawah tegakan jati. Para petani dapat melihat langsung kualitas tegakan jati mega yang pertumbuhannya cepat, penampakannya relatif seragam, diameternya besar, batangnya lurus, dan tidak banyak cabang. Penampakan tegakan jati mega tersebut kualitasnya jauh lebih baik dibandingkan dengan tegakan jati di 
hutan rakyat yang dikelola secara konvensional. Setelah mengikuti studi banding ini, para petani semakin yakin

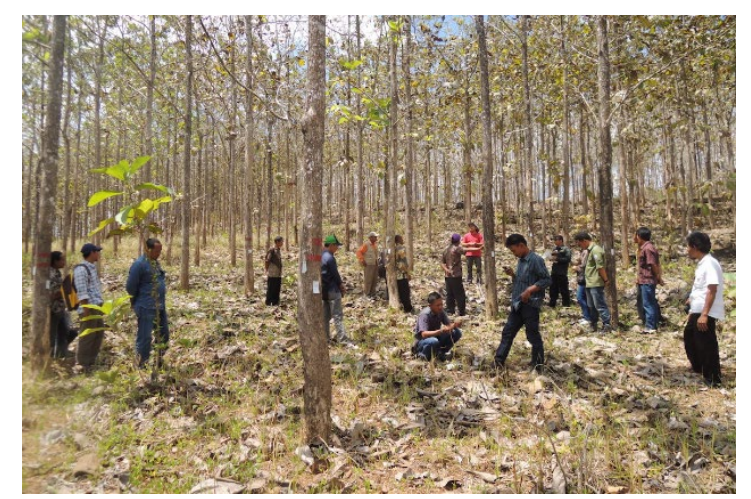

terhadap manfaat dan pentingnya penerapan teknik silvikultur intensif dalam pengelolaan hutan rakyat.

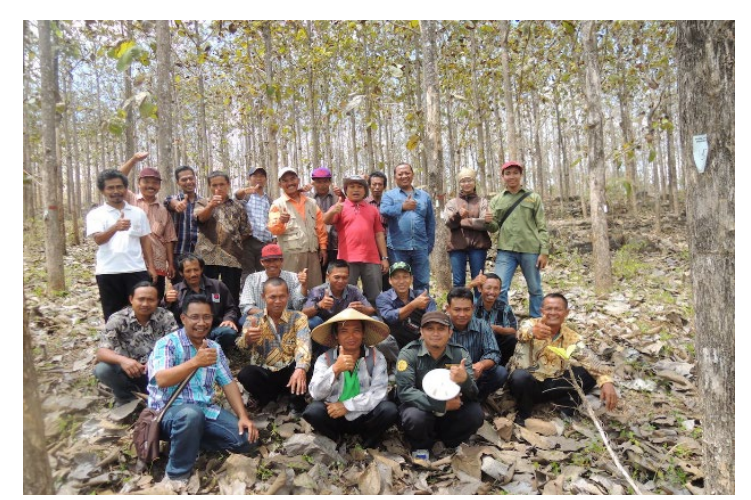

Gambar 5: Studi banding pengelolaan tegakan jati unggul di Wanagama

\section{Pelatihan Teknik SILIN}

Pelatihan teknik SILIN dimaksudkan untuk meningkatkan pemahaman dan ketrampilan petani tentang teknik silvikultur intensif. Pelatihan dilaksanakan sebanyak dua kali, yaitu: (1) Pelatihan teknik silvikultur intensif pada pengelolaan hutan rakyat; (2) Pelatihan teknik pembuatan bibit jati unggul dengan stek pucuk dan pembuatan pupuk organik dengan menggunakan jamur Trichoderma sp. Pada pelatihan pertama para petani hutan rakyat dilatih tentang implementasi teknik silvikultur intensif pada pengelolaan hutan

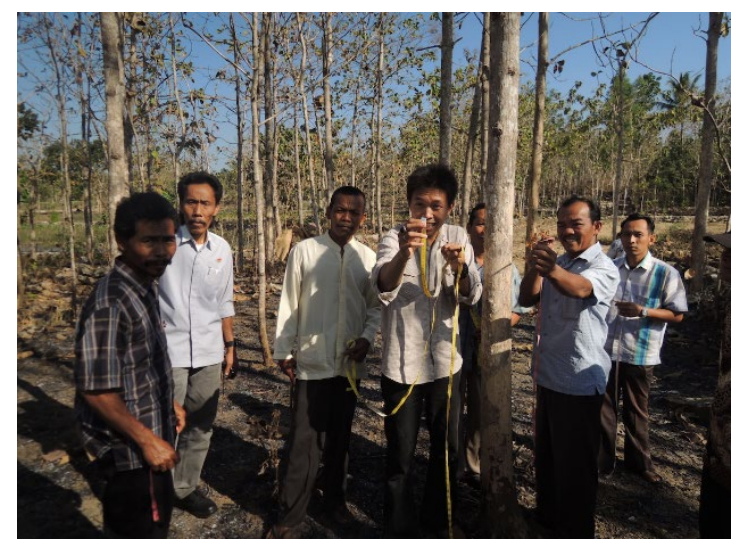

rakyat. Materi pelatihan meliputi cara pemilihan jenis tanaman yang unggul, pengaturan komposisi jenis dan jarak tanam, pemupukan, prunning, penjarangan, pengendalian hama dan penyakit, penaksiran potensi dan pemanenan kayu. Pelatihan dilakukan dengan dua metode, yaitu penjelasan materi di dalam ruangan dan praktek prunning dan penjarangan dilakukan di hutan rakyat milik salah satu pengurus kelompok tani.

Gambar 6: Pelatihan teknik silvikultur intensif pada pengelolaan hutan rakyat

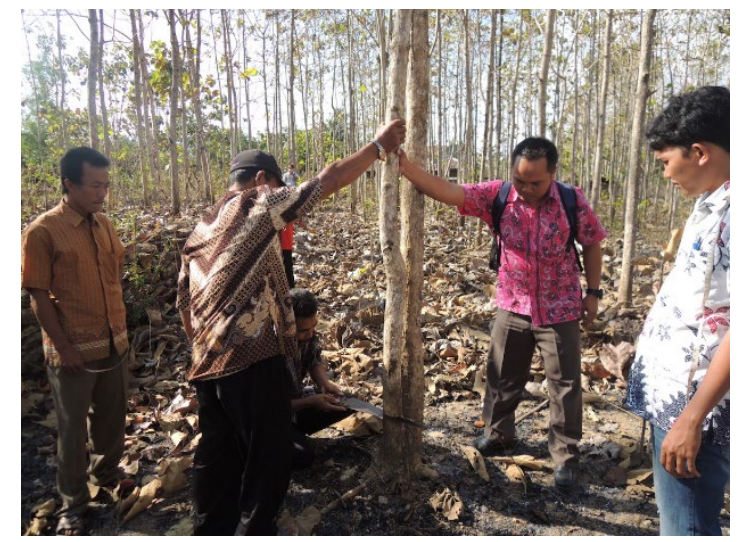

hutan rakyat 
Pada pelatihan kedua para petani dilatih tentang teknik pembuatan bibit jati unggul dengan metode stek pucuk. Pelatihan dilakukan dengan metode ceramah dan diskusi yang dilaksanakan di Balai Dusun Cikal Desa Watusigar. Materi pelatihan meliputi teknik pengelolaan kebun pangkas dan persemaian jati unggul. Para petani dilatih teknik pemilihan pucuk jati yang akan disemaikan, teknik pemanenan atau pemangkasan pucuk, teknik pemberian hormon penumbuh akar, teknik penyiapan media tanam, teknik penanaman semai, teknik penyungkupan, teknik penyiraman dan pemeliharaan semai.

Materi pelatihan selanjutnya adalah teknik pembuatan pupuk organik dengan menggunakan jamur Trichoderma sp. Pupuk organik merupakan pupuk yang berupa senyawa organik (Agus, 2012) atau pupuk

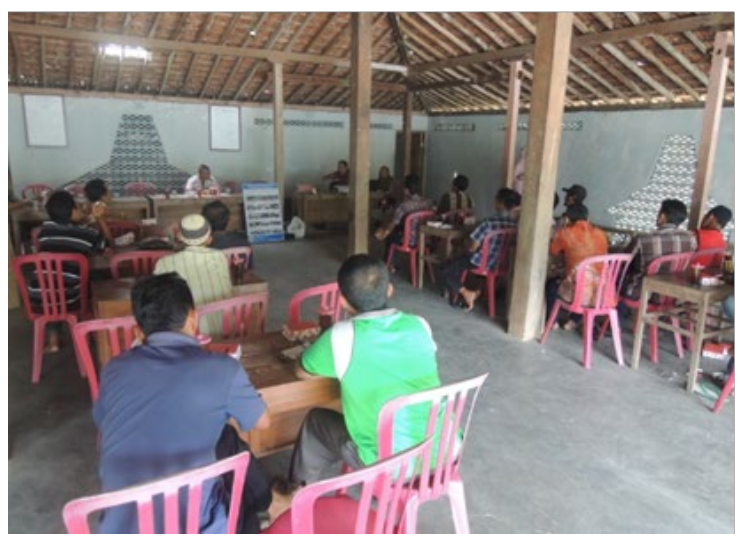

yang terbuat dari bahan-bahan organik seperti pupuk kandang dan kompos. Sementara itu, penambahan jamur Trichoderma sp. pada pupuk organik dimaksudkan sebagai agen hayati yang berfungsi untuk mengendalikan patogen tanah (Gusnawaty, et al., 2014). Penggunaan pupuk organik dengan jamur Trichoderma sp. diharapkan bermanfaat untuk menyuburkan tanah sekaligus dapat mengendalikan jamur patogen penyebab penyakit tanaman. Pada pelatihan ini para petani hutan rakyat dijelaskan tentang kelebihan dan manfaat penggunaan pupuk organik dengan menggunakan jamur Trichoderma sp. Mereka juga dilatih cara memilih dan menyiapkan bahan organik dan bahan pendukung lain yang dibutuhkan untuk pembuatan pupuk organik, serta tahapan-tahapan dan teknik pembuatan pupuk organik.

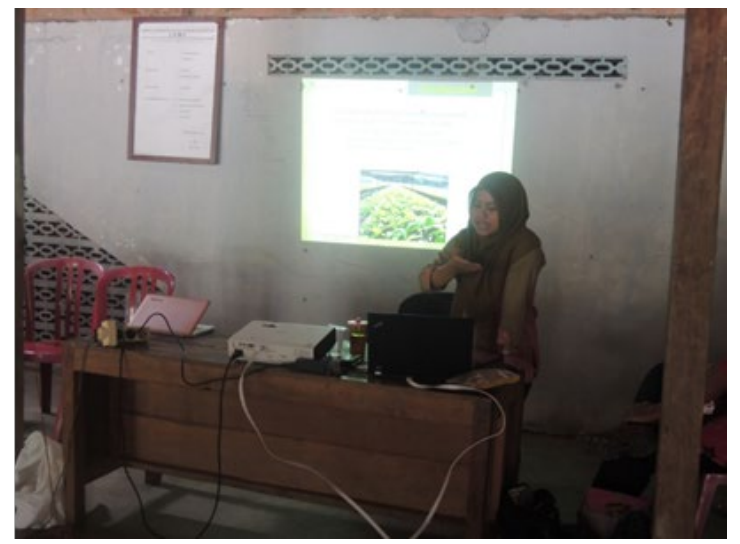

Gambar 7: Pelatihan teknik pembuatan bibit jati unggul dan pupuk organik

Para petani hutan rakyat sangat antausias mengikuti pelatihan. Mereka terlibat aktif dalam setiap penjelasan materi dan diskusi dengan nara sumber. Tingkat keswadayaan petani hutan rakyat dalam pelaksanaan pelatihan juga cukup tinggi. Kondisi ini dibuktikan dengan kesiapan kelompok tani dalam menyediakan tempat pelatihan, bahan-bahan dan peralatan yang dibutuhkan, serta tegakan hutan jati untuk lokasi praktek lapangan. Menurut para petani, pelatihan ini sangat bermanfaat, karena pengetahuan dan ketrampilan yang diperoleh dapat diterapkan untuk meningkatkan produktivitas tegakan hutan rakyat. 


\section{Praktek Implementasi SILIN}

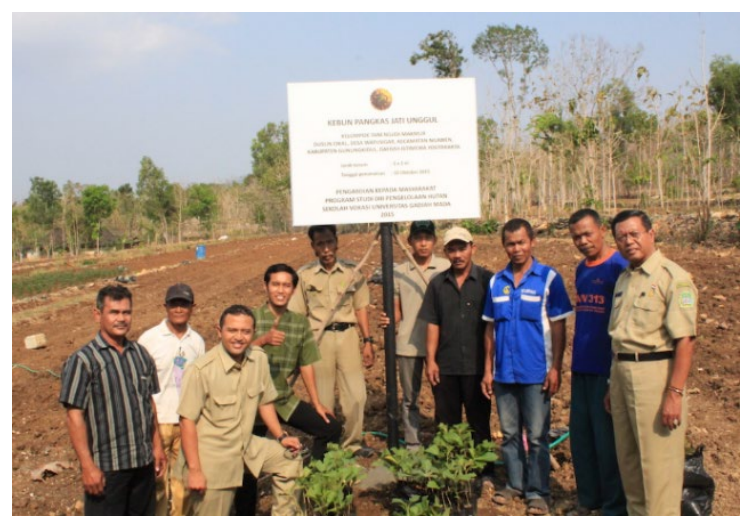

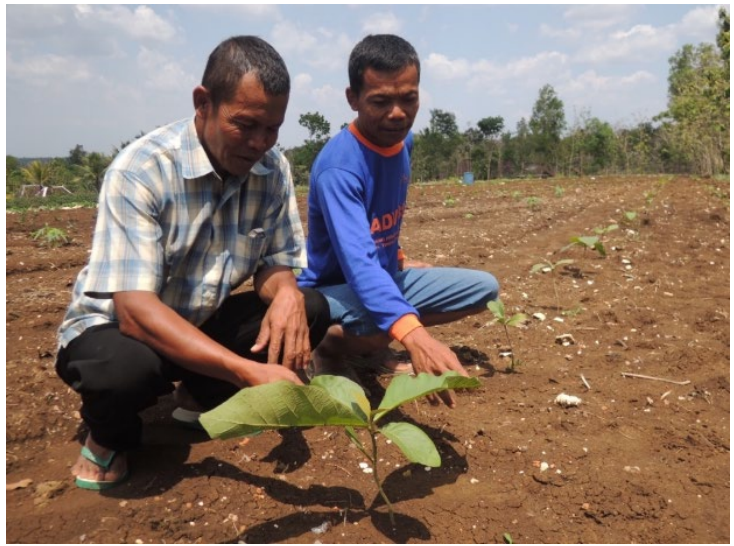

Gambar 8: Pembuatan kebun pangkas jati unggul

Praktek implementasi SILIN dimaksudkan untuk menerapkan ilmu dan ketrampilan tentang teknik silvikultur intensif yang telah diterima oleh para petani hutan rakyat setelah mengikuti sosialisasi, studi banding dan pelatihan. Kegiatan praktek ini meliputi: (1) pembuatan kebun pangkas dan persemaian jati unggul; (2) (3) pembuatan pupuk organik dengan menggunakan jamur Trichoderma sp. Praktek implementasi teknik silvikultur intesif diawali dengan pemberian bantuan indukan bibit jati unggul kepada Kelompok Tani Ngudi Makmur. Indukan bibit jati unggul tersebut merupakan materi dasar untuk pembuatan kebun pangkas dan demplot tegakan jati unggul. Bantuan tersebut sangat berarti bagi petani hutan rakyat karena selama ini mereka kesulitan untuk mendapatkan materi genetik atau indukan jati unggul.

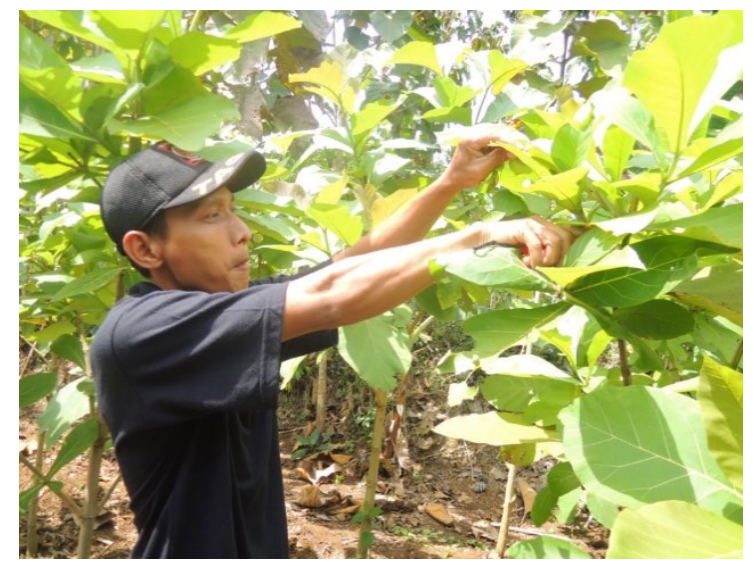

Pembuatan kebun pangkas dimaksudkan untuk menghasilkan material stek pucuk jati unggul guna menopang kebutuhan persemaian. Persemaian merupakan suatu areal yang lokasinya tetap dan sengaja dibangun untuk menghasilkan bibit berkualitas tinggi, dalam jumlah yang besar dan dengan tata waktu yang tepat (Suginingsing dan Ratnaningrum, 2009). Indukan bibit jati unggul ditanam di kebun pangkas dengan jarak tanam 1 x 1 meter. Setelah tumbuh sekitar enam bulan, tanaman jati unggul tersebut kemudian dipangkas dengan ketinggian 1 meter. Setelah pemangkasan kemudian tumbuh tunas-tunas baru pada tanaman jati unggul. Setelah tunas-tunas tersebut berumur $3-4$ minggu kemudian dipanen dengan cara dipangkas untuk selanjutnya disemaikan. Ujung tunas yang dipangkas harus dalam kondisi dorman, agar ketika disemaikan tunas tidak cepat layu atau bahkan mati.

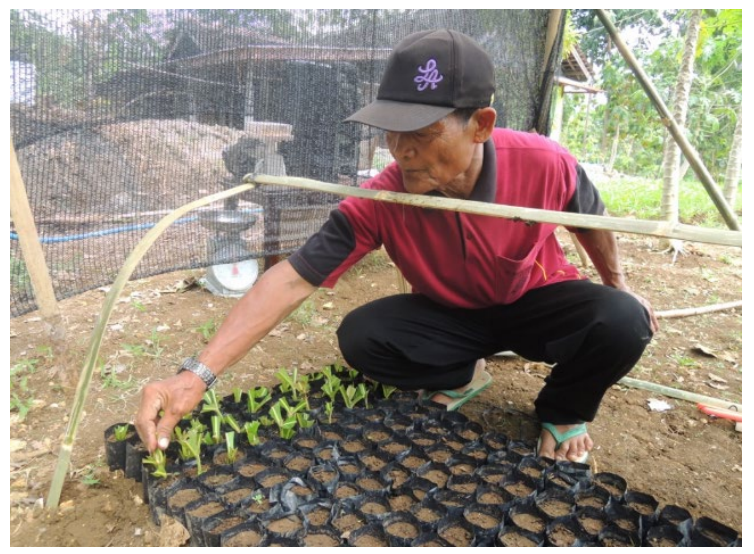

Gambar 9: Pembuatan persemain jati unggul pembuatan demplot tegakan jati tunggul 
Produksi stek pucuk akan semakin banyak seiring dengan bertambahnya umur induk tanaman jati, karena setiap pucuk yang dipangkas akan menghasilkan 2 - 4 cabang tunas baru.

Hasil pemanenan stek pucuk jati unggul dari kebun pangkas selanjutnya disemaikan di persemaian. Tahapan pembuatan semai jati unggul adalah sebagai berikut: (1) pemberian hormon penumbuh akar; (2) penanaman di dalam polybag; (3) penyungkupan semai sampai tumbuh akar; (4) penyiraman dan pemeliharaan semai; (5) aklimatisasi semai dengan cara diberi sinar matahari langsung secara bertahap; (6) semai siap ditanam jika tingginya $30-40$ $\mathrm{cm}$. Proses pembuatan semai jati unggul tersebut memerlukan waktu sekitar 4-6 bulan, dari mulai pemangkasan hingga bibit siap ditanam di lahan.

Pembuatan persemaian ini dimaksudkan untuk membantu para petani hutan rakyat dalam menyediakan bibit jati unggul secara mandiri, yaitu dengan dalam jumlah yang cukup dan harganya terjangkau. Program ini dilakukan karena selama ini petani hutan rakyat masih menghadapi kesulitan memperoleh bibit jati unggul. Para petani hutan rakyat di Gunungkidul pada umumnya masih tergantung kepada pedagang bibit dari luar daerah dalam penyediaan bibit jati unggul. Bahkan saat ini harga bibit jati unggul di tingkat pedagang masih relatif mahal, yaitu berkisar antara Rp 10.000 s.d. Rp 20.000 per batang. Kondisi ini dapat menjadi peluang usaha baru bagi Kelompok Tani Ngudi Makmur, yaitu sebagai penangkar dan pedagang bibit jati unggul. Kegiatan usaha tersebut bukan merupakan hal baru bagi masyarakat Desa Watusigar karena selama ini banyak diantara mereka yang telah menjadi penangkar dan pedagang bibit tanaman hortikultura dan buah-buahan.

Selain ditanam untuk kebun pangkas, sebagian indukan bibit jati unggul juga ditanam untuk pembuatan demplot.
Berbeda dengan kebun pangkas, indukan jati unggul yang ditanam untuk demplot tidak dipangkas tetapi dibiarkan tumbuh meninggi. Pembuatan demplot ini dimaksudkan untuk memberi contoh tegakan jati unggul kepada para petani hutan rakyat. Demplot tegakan jati unggul sengaja ditanam di tepi jalan di sekitar lokasi persemaian supaya mudah dilihat oleh para petani hutan rakyat. Hasil penanaman jati unggul di demplot menunjukkan bahwa pertumbuhannya lebih cepat, batangnya lurus, dan tidak banyak cabang dibandingkan dengan tegakan hutan rakyat konvensional. Dengan demikian diharapkan kepada para petani hutan rakyat termotivasi untuk menanam jati unggul di hutan rakyat.

Sementara itu, pembuatan pupuk organik dengan menggunakan jamur Trichoderma sp. dimaksudkan untuk menyediakan pupuk organik bagi petani hutan rakyat dengan kualitas bagus dan mudah cara pembuatannya. Tahapan pembuatan pupuk organik dengan menggunakan Trichoderma sp. yang telah dilakukan adalah sebagai berikut: (1) menyiapkan bahan-bahan yang diperlukan yaitu pupuk urea $300 \mathrm{gr}$, pupuk TSP $150 \mathrm{gr}$, dolomit 500 gr, jamur Trichoderma sp., kotoran ayam kering $20 \mathrm{~kg}$; (2) mencampur bahan-bahan; (3) mencacah seresah daun;(4) memasukkan seresah dauh yang telah dicacah ke dalam kotak ukuran 1 x 1 m; (5) memasukkan bahan-bahan ke dalam tumpukan seresah daun untuk setiap $25 \mathrm{~cm}$; (6) langkah 4-5 diulang kemudian disiram dengan air hingga jenuh; (7) menutup campuran dengan plastik secara rapat; (8) penyiraman dilakukan setiap pagi dan sore selama 2 minggu; (9) bahan ditutup rapat dengan plastik hingga terdokomposisi sempurna. Proses pembutan pupuk organik dengan menggunakan Trichoderma sp. tersebut membutuhkan waktu sekitar 2,5 - 3 bulan. 

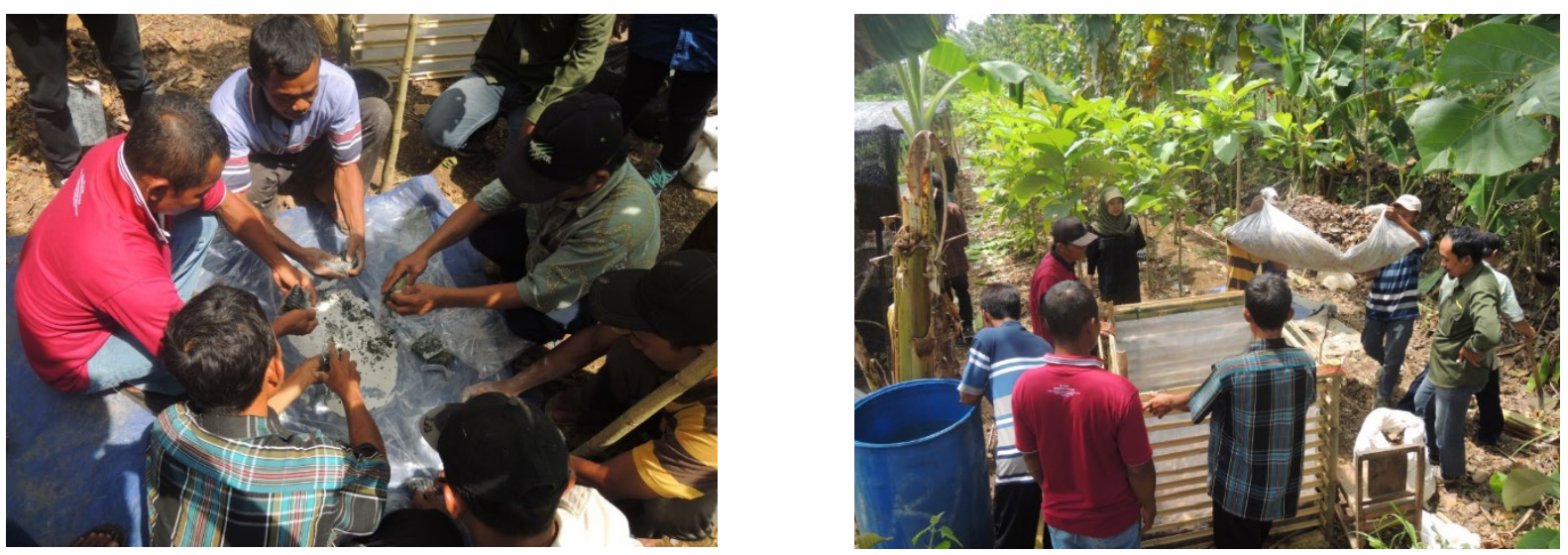

Gambar 10: Pembuatan pupuk organik dengan jamur Trichoderma sp.

Pada kegiatan praktek implementasi SILIN ini terlihat bahwa sikap kegotongroyongan dan keswadayaan para petani hutan rakyat di Desa Watusigar sangat tinggi. Sikap kegotong-royongan ditunjukkan dengan adanya pembagian tugas yang baik diantara para anggota dan pengurus Kelompok Tani Ngudi Makmur dalam menyiapkan kebutuhan bahan-bahan yang dibutuhkan untuk pembuatan persemaian jati unggul dan pupuk organik. Smeentara itu, tingkat keswadayaan petani hutan rakyat ditunjukkan dengan: (1) kesediaan pengurus Kelompok Tani Ngudi Makmur dalam menyediakan lahan untuk lokasi kebun pangkas, persemaian dan demplot jati unggul; (2) pembuatan sumur bor dan pemasangan saluran listrik PLN dengan biaya sampai puluhan juta guna untuk menjamin ketersediaan air bagi persemaian jati unggul.

\section{Pendampingan Petani}

Pendampingan petani dimaksudkan untuk membantu para petani hutan rakyat dalam menyelesaikan kendala-kendala yang dihadapi dalam pengelolaan hutan rakyat secara intensif, termasuk pengelolaan persemaian jati unggul dan pembuatan pupuk organik dengan menggunakan jamur Trichoderma sp. Kegiatan pendampingan dilakukan dengan cara diskusi informal dengan para pengurus kelompok tani dan observasi atau kunjungan ke lokasi tegakan hutan rakyat dan persemaian jati unggul. Dengan cara demikian dapat diketahui dengan pasti berbagai permasalahan yang 68 dihadapi oleh apra petani dalam pengelolaan hutan rakyat dan persemaian jati unggul sehingga segera dapat dicarikan alternatif solusinya. Kegiatan pendampingan ini juga dimaksudkan untuk melakukan monitoring dan evaluasi terhadap pelaksanaan dan hasil program pengabdian kepada masyarakat.

\section{SIMPULAN}

Berdasarkan pelaksanaan kegiatan pengabdian kepada masyarakat ini dapat disimpulkan bahwa: (1) Kegiatan sosialisasi dan studi banding SILIN telah berhasil meningkatkan pemahaman dan kesadaran para petani terhadap pentingnya penerapan teknik silvikultur intensif dalam pengelolaan hutan rakyat; (2) Kegiatan pelatihan SILIN telah berhasil meningkatkan pengetahuan dan ketrampilan para petani tentang teknik pengelolaan tegakan hutan rakyat, teknik pengelolaan kebun pangkas dan persemaian jati unggul, serta pembuatan pupuk organik dengan menggunakan jamur Trichoderma sp.; (3) Kegiatan praktek implementasi SILIN telah mendorong kemandirian para petani hutan rakyat dalam penyediaan bibit jati unggul dan pupuk organik dengan menggunakan jamur Trichoderma sp.; (4) Kegiatan pendampingan telah terbukti efektif membantu petani guna mencari alternatif solusi terhadap berbagai kendala yang dihadapi dalam penerapan teknik silvikultur intensif pada pengelolaan hutan 
rakyat. Pada pelaksanaan kegiatan pengabdian ini juga diketahui bahwa sikap kegotong-royongan dan tingkat keswadayaan para petani hutan rakyat sangat tinggi. Kondisi ini dapat dijadikan pertimbangan untuk pengembangan dan pelaksanaan program pengabdikan kepada masyarakat selanjutnya.

\section{DAFTAR PUSTAKA}

Agus, Cahyono. (2012). Pengelolaan Bahan Organik: Peran dalam Kehidupan dan Lingkungan. Yogyakarta: BPFE.

Anonim. (1999). Undang-Undang Nomor 41 Tahun 1999 tentang Kehutanan.

Awang, S.A., Santoso, H., Widayanti, W.T., Nugroho, Y., Kustomo, dan Sapardiono. (2001). Gurat Hutan Rakyat. Yogyakarta: DEBUT Press

Awang, S.A., Andayani W., Himah, B., Widayanti, W.T., dan Affianto, A.. (2002). Hutan Rakyat: Sosial Ekonomi Pemasaran. Yogyakarta: BPFE

Bappeda DIY. (2015). Pembangunan Kehutanan DIY. www.bappeda.jogjaprov.go.id/jogja _masa_depan/detail/PembangunanKehutanan-DIY. (Diunduh 6 Maret 2015).

Berita Bumi. (2015). Menuju Pengelolaan Hutan Rakyat Lestari Gunungkidul. www.beritabumi.or.id/menujupengelolaan-hutan-rakyat-lestarigunungkidul/. (Diunduh 6 Maret 2015).

Hinrich, A, D.R. Muhtaman, dan N. Irianto. (2008). Sertifikasi Hutan Rakyat di Indonesia. Jakarta: GTZ

Gusnawaty, H.S, Taufiq, M., Triana, L., dan Asniah. (2014). Karakteristik Morfologis Trichoderma spp. Indigenus Sulawesi Tenggara. Jurnal Agroteknos. 4:87-93

Naiem, M. (2005). Upaya Peningkatan Kualitas Hutan Jati Rakyat. Dalam Mahfudz, Mirsatmanto A, dan Fauzi $M A$ (eds). Prosiding Pertemuan Forum Komunitas Jati IV: Pengembangan Benih Jati Unggul untuk Peningkatan Produktivitas Hutan Rakyat.

Pramono, A.A., Fauzi, M.A., Widyani, N., Heriansyah, I. dan Roshetko, J.M. (2010). Pengelolaan Hutan Jati Rakyat: Panduan Lapangan untuk Petani. Bogor: CIFOR.

Simon, H. (2010). Dinamika Hutan Rakyat di Indonesia. Yogyakarta: Pustaka Pelajar

Soekotjo. (2009). Teknik Silvikultur Intensif (SILIN). Yogyakarta: Gadjah Mada University Press.

Suginingsih dan Y.W.N., Ratnaningrum. (2009). Bahan Ajar Aplikatif Teknik Persemaian. Yogyakarta: Datamedia. 
